日消外会誌 $43 （ 10 ）: 1048 １ 053 ， 2010$ 年

症例報告

腎移植後被囊性腹膜硬化症による腸閉塞で手術を要した 1 例

\begin{tabular}{lccccc}
\multicolumn{5}{c}{ 九州大学臨床・腫瘍外科 } & \\
錦 & 建宏 & 北田 & 秀久 & 土井 & 篤 \\
三浦 & 敬史 & 栗原 & 啓 & 田中 & 雅夫
\end{tabular}

腎移植 3 年後に被囊性腹膜硬化症 (Encapsulated Peritoneal Sclerosis；以下，EPS)による腸 閉塞で手術を要した 1 例を経験したので報告する. 症例は 54 歳の男性で, 14 年間の腹膜透析歴 を有し， 2004 年 5 月に献腎移植を施行した。腎機能は良好だったが，3 年後に EPSによる腸閉 塞を繰り返し，内科的治療は困難と判断し，外科的治療を施行した。開腹後，骨盤内に硬化性 偽膜に包まれた腸管が白色の塊を形成し癒着していたため，偽膜を剥離し癒着を解除した．経 過良好で術後 13 日目退院となった，EPSの治療は，腸管安静，ステロイド，免疫抑制剂などが 基本だが，内科的治療に抵抗する腸閉塞症状がある場合，腸管癒着剥離を基本とする外科的介 入が必要となる，また，腹膜透析後の腎移植は，ステロイド，免疫抑制剤の服用にもかかわら ず, EPS を増悪させるとの報告があり，腹膜透析患者に対する腎移植は EPS の進行を念頭に入 れ，腸閉塞症状が高度となった場合は，外科的治療も検討する必要がある.

\section{はじめに}

末期腎不全に対する治療法は，血液透析，腹膜 透析，腎移植の三つがあり，患者の生命予後・ quality of life (以下, QOL) を考えると，腎移植が 最も理想的ではあるが1), ドナー不足という根本的 問題があり, 透析療法が長期化する傾向にある2 腹膜透析では血液透析に比べ, 在宅で施行可能な ど QOL の点で有利である反面 ${ }^{3}$, 被囊性腹膜硬化 症 (encapsulating peritoneal sclerosis ; 以下, EPS)が問題となる ${ }^{2)}$. 今回, 腹膜透析歴 14 年を有 する患者に献腎移植を施行した 3 年後に EPSに よる腸閉塞を発症し, 外科的治療を要した症例を 経験したので報告する.

\section{症例}

症例 : 54 歳, 男性

主訴 : 嘔吐, 左下腹部痛

現病歴 : 幼少時にネフローゼ症候群と診断さ れ, 徐々に腎機能が悪化. 1986 年末期腎不全とな り，血液透析導入となった. 1988 年, 本人の希望

$<2010$ 年 3 月 24 日受理 $>$ 別刷請求先 : 錦 建宏 T 812-8582 福岡市東区馬出 3-1-1 九州大学臨 床・腫瘍外科
で，腹膜透析に変更．腹膜機能低下のため, 2002 年に血液透析再導入となった. 2004 年 5 月, 献腎 移植を施行，その後経過は良好であった。 2007 年 5 月, 腸閉塞で緊急入院となり保存的治療で軽 快したが, 2007 年 6 月, 再び腸閉塞を発症して緊 急入院となった.

既往歴：2004 年副甲状腺全摘術 + 左前腕自家 移植術, 2006 年 5 月 $\cdot 2007$ 年 4 月急性腸炎

現症 : 左上腹部に圧痛, 反跳痛を認めたが, 筋 性防御は認めなかった。右下腹部に献腎移植, 左 下腹部に腹膜透析チューブ挿入術の手術㓔痕を認 めた。

入院時検查所見 : $\mathrm{BUN}$ と $\mathrm{Cr}$ の上昇を認めた が，腎移植後の值とほぼ同值であった，白血球の 増加と軽度の CRP 上昇を認めた（Table 1).

腹部レントゲン写真 : 腹部全体に Niveau と小 腸の拡張像を認めた（Fig.1A，B）.

腹部単純 $\mathrm{CT}$ : 大網, 腹膜の小範囲に石灰化と 小腸に高度の拡張と液面形成を認め, 骨盤内右側 の遠位小腸の集簇部が閉塞起点となる腸閉塞の所 見を認めた（Fig. 2A，B）.

入院後の経過：イレウス管を抻入して保存的治 
Fig. 1 A : Upright abdominal radiograph showing many niveaus. B : Supine abdominal radiograph showing gaseous distention of the small intestine.
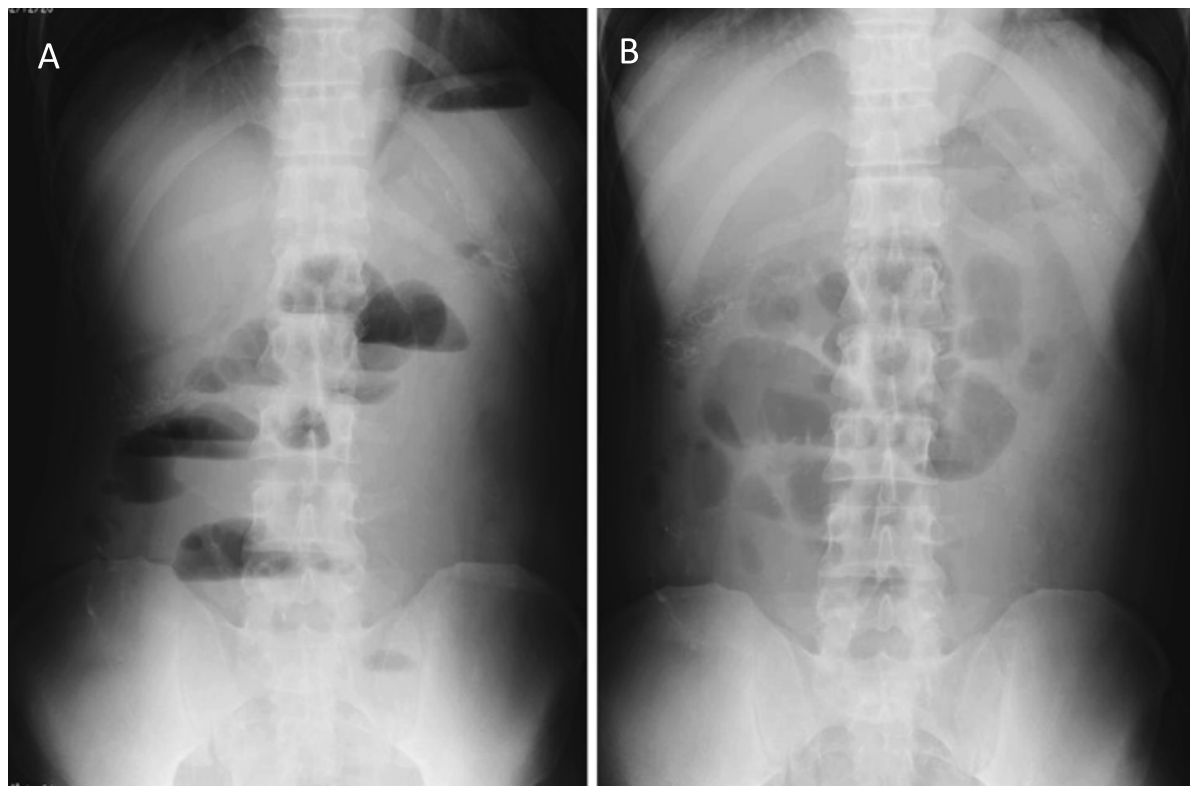

Table 1 Laboratory data

\begin{tabular}{|c|c|c|c|}
\hline \multicolumn{2}{|c|}{ Peripheral blood count } & \multicolumn{2}{|c|}{ Chemistry } \\
\hline WBC : & $11,700 / \mu \mathrm{L}$ & TP : & $6.8 \mathrm{~g} / \mathrm{dl}$ \\
\hline $\mathrm{RBC}:$ & $3.45 \times 10^{6} / \mu \mathrm{L}$ & ALB & $4.0 \mathrm{~g} / \mathrm{dl}$ \\
\hline $\mathrm{Hb}:$ & $10.5 \mathrm{~g} / \mathrm{dl}$ & $\underline{\text { BUN : }}$ & $24 \mathrm{mg} / \mathrm{dl}$ \\
\hline $\mathrm{Ht}$ & $32.8 \%$ & Cr: & $1.89 \mathrm{mg} / \mathrm{dl}$ \\
\hline \multirow{2}{*}{\multicolumn{2}{|c|}{ PLT : $26.9 \times 10^{4} / \mu \mathrm{L}$}} & $\mathrm{UA}$ : & $7.0 \mathrm{mg} / \mathrm{dl}$ \\
\hline & & $\mathrm{Ca}:$ & $6.5 \mathrm{mg} / \mathrm{dl}$ \\
\hline \multicolumn{2}{|c|}{ Coagulation test } & $\mathrm{P}:$ & $4.3 \mathrm{mg} / \mathrm{dl}$ \\
\hline PT : & $12.4 / 11.5 \mathrm{sec}$ & $\mathrm{Na}:$ & $137 \mathrm{mmol} / \mathrm{l}$ \\
\hline APTT : & $35.5 / 35.8 \mathrm{sec}$ & K & $4.6 \mathrm{mmol} / \mathrm{l}$ \\
\hline \multirow[t]{8}{*}{ FDP : } & $3.1 \mu \mathrm{g} / \mathrm{l}$ & CK : & $99 \mathrm{U} / \mathrm{L}$ \\
\hline & & ALP : & $275 \mathrm{U} / \mathrm{L}$ \\
\hline & & T-BIL : & $0.6 \mathrm{mg} / \mathrm{dl}$ \\
\hline & & AST : & $21 \mathrm{U} / \mathrm{L}$ \\
\hline & & ALT : & $23 \mathrm{U} / \mathrm{L}$ \\
\hline & & GLU : & $99 \mathrm{mg} / \mathrm{dl}$ \\
\hline & & CRP : & $0.13 \mathrm{U} / \mathrm{L}$ \\
\hline & & \multicolumn{2}{|c|}{ Intact-PTH : $107 \mathrm{pg} / \mathrm{dl}$} \\
\hline
\end{tabular}

療を開始したが, イレウス管排液が多量で減少傾 向がなく，第 5 病日にイレウス解除術を行った.

手術所見：下腹部正中切開で腹腔内に達すると 多量の腹水を認め, 小腸は拡張 - 腫脹し, 骨盤内 に硬化性偽膜に包まれた腸管が白色の塊を形成,
癒着し，口側で通過障害を起こしていた (Fig. 3). そのほかの小腸, 腹膜にも硬化性偽膜を認め, 小 腸全貌が観察できるまで偽膜を剥離して癒着を解 除し，ドレーンを挿入して閉腹し，手術を終了し た。

術後経過：術後 3 日目には排ガス, 排便を認め, 術後 6 日目にイレウス管抜去, 術後 7 日目に食事 を開始した.その後の経過も良好で術後 13 日目に 退院した. 2009 年 3 月現在, 腎機能は良好で, 腸 閉塞も発症していない.

\section{考察}

腹膜透析は血液透析に比べ, 在宅で施行可能で あるなど QOL の点で有利であるが，透析治療の 約 3\% を占めるにとどまっており，カテーテル留 置による腹膜炎・長期透析による腹膜機能・濾過 能の劣化, EPSの併発が問題となっている.

EPS とは腹膜劣化により変性した腸管壁同士 が癒着，表面が白色被膜に覆われ，持続的・間欠 的あるいは反復性に腸閉塞症状を呈する症候群で ある。その定義は明確ではなく，硬化性腹膜炎 (sclerosing peritonitis；SP), 腹膜硬化症 (perito- 
Fig. 2 A, B : Abdominal CT scans showing carcification of mesentry and peritoneum (arrow 1) and a niveau (air-fluid level) in distended small bowel (arrow 2).
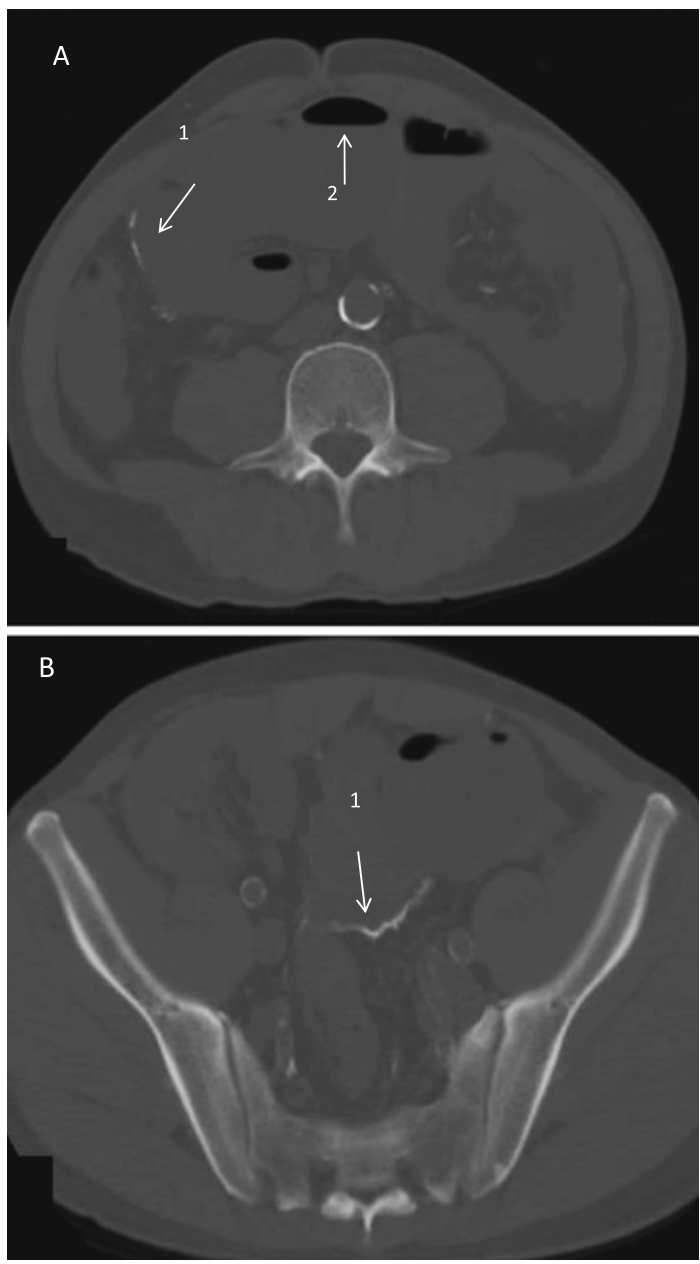

neal sclerosis), 腹膜線維症 (peritoneal fibrosis), 硬化性被囊性腹膜炎 (sclerosing encapsulating peritonitis ; SEP) とも称される ${ }^{4)}$. 臨床症状は, 初 期は嘔吐・下痢・腹痛などの消化器症状とともに 発熱・体重減少・倦怠感を認め, 進行すると腸閉 塞症状が顕著となる。被囊が完成すると腹部に塊 状物が触知されることもあり，致死的になること もありうる合併症である。発症因子として，長期 使用による腹膜劣化, 高張透析液, 腹膜炎などが あげられ，腹膜透析期間が重要であるとされる5. 透析期間が長期になれば，EPSの発症率は上昇
Fig. 3 A portion of the small intestine is entrapped in a dense white fibrous capsule and was adhesive intricately in the pelvis, causing intestinal obstruction.

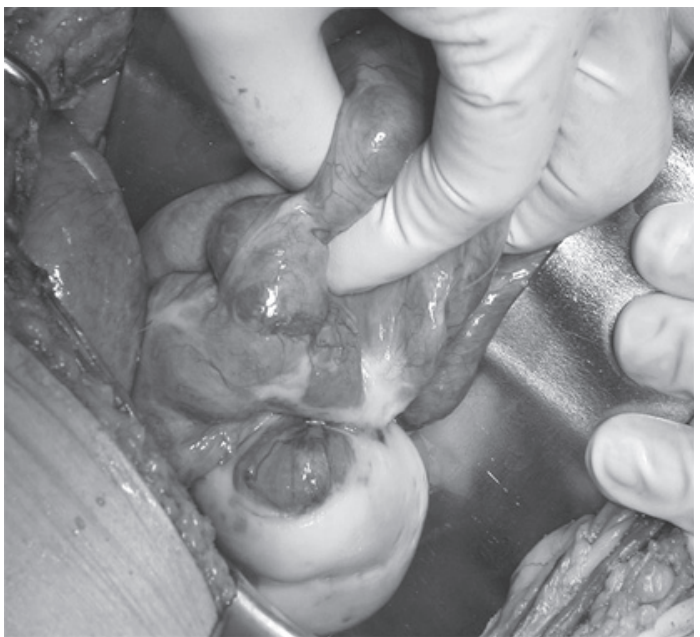

し，透析期間が 5 年を超えると $8 \%, 8$ 年を超える と $19 \%$ に上昇すると報告されている ${ }^{6}$. 今回の症 例では，肉眼所見で白色の被膜を認め（Fig. 3）, 高度な硬化性肥厚を伴っていた。また，14年間に 及ぶ長期の腹膜透析歴を有しており, 今回の EPS 発症の誘因の一つと思われる.

腹膜透析中の EPSの予防は腹膜の劣化を防ぐ ことであり，生体適合性の良い透析液の使用，力 テーテルに起因する腹膜炎の防止が必要とされ る。発症した場合は，腹膜透析の中止による腸管 の安静が治療の基本である。一方, 腹膜透析中止 後は, 腹膜洗浄やステロイド・免疫抑制剤内服が EPS 発症の予防として有効とする報告もある が7) $^{7)}$ ，一定の見解は得られていない。本症例では HD 再導入後より, EPS 予防のためプレドニゾロ ンの内服が, 腎移植後は免疫抑制目的でプレドニ ゾロン・シクロスポリン・ミコフェノール酸モ フェチルが投与されていたにもかかわらず，腎移 植後 3 年目にEPSによる腸閉塞を発症している.

内科的治療に抵抗する腸閉塞症状がある場合 は, 外科的介入が必要となってくる. EPSの外科 的治療の基本は腸管癒着剥離術である. 腹膜透析 後の EPS に対する開腹腸管癒着剥離術が飛躍的 
に生存率を上昇させたとの報告もあるが99, EPS 腸閉塞に対し, 腸管癒着剥離術を施行した 57 症例 中 2 例に死亡例を認めた報告もある ${ }^{10)}$. また, 腹膜 石灰化が高度である場合, 腸管固有筋層に石灰化 が達しており, 創傷治癒が困難なため, 腸管切除・ 吻合は原則禁忌とされる。川西ら ${ }^{11}$ は EPS 腸閉塞 に対し, 腸管切除・吻合を行った 11 例中 9 例が死 亡したと報告している. 一方, 大森ら ${ }^{12)}$ は腎移植後 に発症した EPS 腸閉塞に対し, 腸管切除・吻合を 行っており, 石灰化変性のない色調のよい切除腸 管の選択, 術後腎機能の安定が良好な結果を生ん でいると報告している．本症例は腸管切除を行わ ず, 癒着剥離のみで軽快したが, 内科的治療に抵 抗する腸閉塞症状がある場合は, 腸管切除を要す る重篤な病態となる前に, 腸管癒着剥離術を検討 する必要があると思われる.

腸閉塞の再発, 癒着防止に対し，ステロイドの 腹腔内投与, シリコンラバー性薄膜シート, 生体 適合バイオポリマー吸収性薄膜の効果が報告され ている ${ }^{1314)}$. 本症例では, 免疫抑制下であり, 感染 症を考慮し，使用しなかった。

1983 年から 2009 年 12 月まで医学中央雑誌で 「被囊性腹膜硬化症」「硬化性被囊性腹膜炎」「腎移 植」をキーワードに検索し，全年でPub Med を用 いて「Encapsulated Peritoneal Sclerosis」と「Sclerosing peritonitis」と「Renal Transplantation」の かけ合わせで検索した。そそ結果，腹膜透析後の EPS 発症頻度は Australia では $0.7 \%{ }^{15)}$, Great Britainの単一施設で $3.3 \%{ }^{16)}$, 日本では $2.5 \%{ }^{17)}$ と 報告されており, 腎移植後の EPS 発症例は 13 報 告 37 例に認めた ${ }^{1218) ~ 29)}$. 腹膜透析を介した腎移植 におけるEPSの発症率を解析した報告は検索し えなかったが, 志々田ら ${ }^{28)}$ は, EPS を発症した 126 症例のうち, 腎移植 $(n=7)$, 非移植 $(n=119)$ を 比較し, 腹膜透析期間, 腹膜透析から EPS 発症期 間, カテーテル抜去から EPS 発症期間, EPS 発症 から手術までの期間のいずれも有意差を認めな かったと報告している.

一方, 腎移植は EPS を増悪させるとの報告があ る. 腹膜透析中止・腎移植手術が, 腹腔内のフィ ブリン濃度・前炎症性サイトカイン・フィブリン
促進メディエーターを増加させ，フィブリン化を 促進させることが原因とされている ${ }^{23)}$. そのため, 移植後の腹膜洗浄を推奨する報告も散見される が, その効果には一定の見解が得られていないこ と, 免疫抑制下での腹膜透析カテーテルに起因す る腹膜炎発症を考慮し ${ }^{30)}$, 当科では腹膜透析症例 に腎移植を施行する際，移植手術と同時にカテー テルを抜去している．本症例は腎移植前より EPS を指摘され, 移植後も急性腸炎様症状を繰り返し ていた. 腎移植手術が EPS を促進させた可能性は 否定できない. しかし, 腎移植による生命予後・ QOL の改善は明らかであり, EPS 発症を懸念し て腎移植を断念するのは本末転倒の話である．腹 膜透析患者の腎移植後に EPS が発症することを 常に念頭に置き, 下痢・嘔吐などの消化器症状が 出現した場合には，免疫抑制剂による消化器症状 や感染性腸炎のほかに, EPSの可能性も常に念頭 に入れ，治療にあたる必要がある。

今回, 腹膜透析歴 14 年の腎不全患者に献腎移植 を施行後 3 年目にEPS 腸閉塞で手術を施行した 症例を経験した。腹膜透析患者への腎移植は EPS を増悪させる可能性もあり, 予防・治療的効果が 期待されるステロイド・免疫抑制剤が投与されて いても, EPSの進行を念頭に入れ, 腸閉塞症状が 高度となった場合には, 外科的治療も検討する必 要があると思われる.

\section{文献}

1) Volfe RA, Ashby VB, Milford EL et al : Comparison of mortality in all patients on dialysis, patients on dialysis awaiting transplantation, and recipients of first cadaveric transplant. N Engl J Med $341: 1725-1730,1999$

2）坂井 謙：血液透析・腹膜透析・腎移植どの療 法を選ぶか? 透析ケア 13:337一-341, 2007

3) Van Biesen W, Vanholder RC, Veys N et al : An evaluation of an integrative care approach for end-stage renal disease patients. J Am Soc Nephrol 11: 116-125, 2000

4) Gandli VC, Humayan HM, Ing TS et al : Sclerotic thickening of the peritoneal membrane in maintenance peritoneal dialysis patients. Arch Intern Med 140 : 1201-1203, 1980

5）中村 玲, 水口 潤：被囊性腹膜硬化症（硬化性 腹膜炎)。腎と透析 61 (臨増)：604-606, 2006

6) Kawanishi H, Moriishi M : Epidemiology of en- 
capsulating peritoneal sclerosis in Japan. Perit Dial Int 25 (suppl 4) : S14-18, 2005

7) Junor BJR, McMillan MA : Immunosupression in sclerosing peritonitis. Adv Perit Dial 9 : 187189, 1993

8) Breborowicz A, Oreopoulos DG : Is normal sarine harmful to the peritoneum? Perit Dial Int 25 (suppl 4) : S67-70, 2005

9) Kawanishi H, Watanabe H, Moriishi M et al : Successful surgical management of encapsulating peritoneal sclerosis. Perit Dial Int 25 (suppl 4) : S39-47, 2005

10) Kawanishi $H$ : Surgical treatment for encapsulating peritoneal sclerosis. Adv Perit Dial 18 : 139143,2002

11）川西秀樹, 川口良人：硬化性被囊性腹膜炎 (SEP) の全国調査一1998 年 11 月の結果一。腎と透析 49 (別冊) : 225一228, 2000

12）大森健太郎, 小川 麻, 近藤大介ほか：生体腎移 植後に硬化性被囊性腹膜炎 (SEP) による腸閉塞を 発症したが外科的治療で改善した 1 例. 腎と透析 62 (別冊) : 75一79, 2007

13）吉田孝太郎，板橋道朗，亀岡信悟ほか：イレウス 手術時期決定と術式の選択. 外科治療 86 ： 1136-1140, 2002

14) Uchida K, Urata H, Mohri Y et al : Seprafilm does not aggravate intraperitoneal septic conditions or evoke systemic inflammatory response. Surg Today $35:$ 1054-1059, 2005

15) Rigby RJ, Hawley CM : Sclerosing peritonitis : the experience in Australia. Nephrol Dial Transplant 13 : 154-159, 1998

16) Summers AM, Clancy MJ, Syed F et al : Singlecenter experience of encapsulating peritoneal sclerosis in patients on peritoneal dialysis for endstage renal failure. Kidney Int $68: 2381-2388$, 2005

17) Kawanishi H, Kawaguchi Y, Fukui H et al : Encapsulating peritoneal sclerosis in Japan : a prospective, controlled, multicenter study. Am J Kidney Dis $44: 729-737,2004$

18) Machado DJ, Cocuzza CS, Nahas WC et al : Sclerosing encapsulating peritonitis after renal transplantation. Does it make sense? Perit Dial Int $20: 341-343,2000$
19) Kawanishi H, Harada $Y$, Sakikubo E et al : Surgical treatment for sclerosing encapsulating peritonitis. Adv Perit Dial 16 : 252-256, 2000

20) Dejagere T, Evenepoel P, Claes K et al : Acuteonset, steroid-sensitive, encapsulating peritoneal sclerosis in a renal transplant recipient. Am J Kidney Dis 45 : e33-37, 2005

21) Kawanishi H, Watanabe H, Moriishi M et al : Successful surgical management of encapsulating peritoneal sclerosis. Perit Dial Int 25 (Suppl 4) : S39-47, 2005

22) Moustafellos P, Hadjianastassiou V, Roy D et al : Tamoxifen therapy in encapsulating sclerosing peritonitis in patients after kidney transplantation. Transplant Proc 38 : 2913-2914, 2006

23) Fieren MW, Betjes MG, Korte MR et al : Posttransplant encapsulating peritoneal sclerosis : a worrying new trend? Perit Dial Int $27: 619-624$, 2007

24) Mohamed AO, Kamar N, Nogier MB et al : Tamoxifen therapy in kidney-transplant patients presenting with severe encapsulating peritoneal sclerosis after treatment for acute humoral rejection. Exp Clin Transplant 7 : 164-167, 2009

25）増子佳弘, 久木田和丘, 目黒順一ほか：連続携行 式腹膜透析における硬化性被囊性腹膜炎症例の 検討. 北海道外科誌 $46: 44-49,2001$

26）百瀬昭志，橋本安弘，佐藤元昭ほか：被囊性腹膜 硬化症を腎移植 3 年後に発症した 1 例. 日本透析 医学会雑誌 36 : 1437-1442,2003

27）一森敏弘, 阪田章聖, 宇山 攻ほか：被囊性腹膜 硬化症の前段階時期の 3 症例。腎と透析 57 (別冊)：434一-437, 2004

28）志々田将幸, 川西秀樹, 森石みさきほか：腎移植 後に被囊性腹膜硬化症を発症し, 外科的治療にて 治癒した 3 例。腎と透析 66 (別冊) : $51-54$, 2009

29）丹野有道, 山本裕康 : 腹膜透析 (PD) の功罪 腎 移植後の被囊性腹膜硬化症. 今日の移植 22 : 447-451, 2009

30) Arbeiter K, Picher A, Muerwald G et al : Timing of peritoneal dialysis catheter removal after pediatric renal transplantation. Perit Dial Int 21 : 467-470, 2001 


\title{
Intestinal Obstruction due to Encapsulated Peritoneal Sclerosis after Renal Transplantation
}

\author{
Takehiro Nishiki, Hidehisa Kitada, Atsushi Doi, \\ Yoshifumi Miura, Kei Kurihara and Masao Tanaka \\ Department of Surgery and Oncology Graduate School of Medical Sciences Kyushu University
}

We report a case of encapsulated peritoneal sclerosis (EPS) requiring surgery three years after renal transplantation. A 54-year-old man treated by peritoneal dialysis for 14 years underwent cadaveric donor renal transplantation. Three years after the transplant, the patient developed intestinal obstruction resulting from EPS. Emergency surgery showed the small intestine to be encapsulated in white fibrous tissues. Enterolysis with resection of the white capsule relieved the intestinal obstruction, and the man was discharged 13 days after operation. Basic EPS treatment includes bowel rest, steroids, and immunosuppressive agents, but the pathological response is poor. Some reports discuss the exacerbation of EPS after kidney transplant, despite the administration of steroids and immunosuppressive agents. This fact should be kept in mind in follow-up for kidney transplant recipients with a history of peritoneal dialysis.

Key words : renal transplantation, peritoneal dialysis, encapsulating peritoneal sclerosis (EPS)

[Jpn J Gastroenterol Surg $43:$ 1048-1053, 2010]

Reprint requests : Takehiro Nishiki Department of Surgery and Oncology Graduate School of Medical Science Kyushu University

3-1-1 Maidashi, Higashi-ku, Fukuoka, 812-8582 JAPAN

Accepted : March 24, 2010

(C)2010 The Japanese Society of Gastroenterological Surgery Journal Web Site : http ://www.jsgs.or.jp/journal/ 